\title{
Antarctica and Global Paleogeography: From Rodinia, Through Gondwanaland and Pangea, to the Birth of the Southern Ocean and the Opening of Gateways
}

\author{
T. H. Torsvik, ${ }^{1,2}$ C. Gaina, ${ }^{l}$ and T. F. Redfield ${ }^{1}$
}

\begin{abstract}
Neoproterozoic Rodinia reconstructions associate East Antarctica (EANT) with cratonic Western Australia. By further linking EANT to both Gondwana and Pangea with relative plate circuits, a Synthetic Apparent Polar Wander (SAPW) path for EANT is calculated. This path predicts that EANT was located at tropical to subtropical southerly latitudes from ca. $1 \mathrm{Ga}$ to $420 \mathrm{Ma}$. Around $400 \mathrm{Ma}$ and again at $320 \mathrm{Ma}$, EANT underwent southward drift. Ca. 250 Ma Antarctica voyaged briefly north but headed south again ca. $200 \mathrm{Ma}$. Since 75 Ma EANT became surrounded by spreading centers and has remained extremely stable. Although paleomagnetic data of the blocks that embrace West Antarctica are sparse, we attempt to model their complex kinematics since the Mesozoic. Together with the SAPW path and a revised circum-Antarctic seafloor spreading history we construct a series of new paleogeographic maps.
\end{abstract}

\section{INTRODUCTION}

Antarctica is the world's last discovered wilderness, still relatively poorly mapped, and the only continent without an indigenous human history. Excepting the very tip of the Antarctic Peninsula, the bulk of the Antarctic land mass lies south of the Antarctic circle, and is covered by ice on a year-round basis. Constrained to isolated nunataks, mountain chains, and coastal exposures, geological studies have been

${ }^{1}$ Center for Geodynamics, Geological Survey of Norway, Leiv Eirikssons vei 39, NO-7491 Trondheim (Norway) (trond.torsvik@ngu.no).

${ }^{2}$ Also at PGP, University of Oslo, 0316 Oslo (Norway); School of Geosciences, Private Bag 3, University of Witwatersrand, WITS, 2050 (S. Africa). correspondingly limited in scope. Geophysical techniques capable of resolving rock properties beneath the ice cover have proved helpful to delineate the continent's crustal structure, but often fail to shed light on Antarctica's geotectonic evolution. Thus, Antarctica remains the most geologically unexplored continent.

Extending from the Ross to the Weddell Seas, the Transantarctic Mountains (Figure 1) effectively divide Antarctica into two geological provinces: cratonal East Antarctica (EANT) and the collage of tectonic blocks that make up West Antarctica (WANT). Possessed of a long, globetrotting history, portions of EANT can be traced to Rodinia and perhaps even beyond. As a relative newcomer to the paleogeographic parade, WANT comprises discrete tectonic blocks (Figure 1) separated by rifts or topographic depressions.

Today the Antarctic plate is neighbored by six different tectonic plates and almost entirely surrounded by spreading ridges. This tectonic configuration has in part given rise to Antarctica's near-total Cenozoic isolation. Two important hotspots (Kerguelen, Marion) lie within the Antarctic plate. The Bouvet hotspot, which may have been responsible for the catastrophic Karroo igneous outpouring in Jurassic time, is now located near the AFR-SAM-ANT triple junction (Figure 2). In this review we outline the location of the world's fifth largest continent and its neighbors in space and time, and present paleogeographic reconstructions for important periods of assembly and breakup. We give a list of acronyms used in Table 1.

\section{EAST ANTARCTICA IN SPACE AND TIME}

EANT comprises Archaean and Proterozoic-Cambrian terranes that amalgamated during Precambrian and Cambrian times (Fitzsimons, 2000; Harley, 2003). Proterozoic base- 
FIGURE 1 Antarctic topography and bathymetry. East Antarctica is subdivided into four provinces (Lythe et al., 2000): DML, LHB, RAY, and a large undivided unit (EANT). West Antarctica consists of five major distinctive terranes: AP (comprising Eastern-Central-Western domains: ED-CD-WD), TI, FB, MBL, and EWM. The three northern Victoria Land terranes are grouped together (NVL). ROSS $=$ extended continental crust between MBL and EANT; TAM = Transantarctic Mountains (red and black lines). Most of the circumAntarctic continent ocean boundaries (outermost polygon boundaries) are the result of nonvolcanic breakup except NW of DML (volcanic; red line) and Western AP (inactive trench, white and red lines) (see Table 1 for more abbreviations).

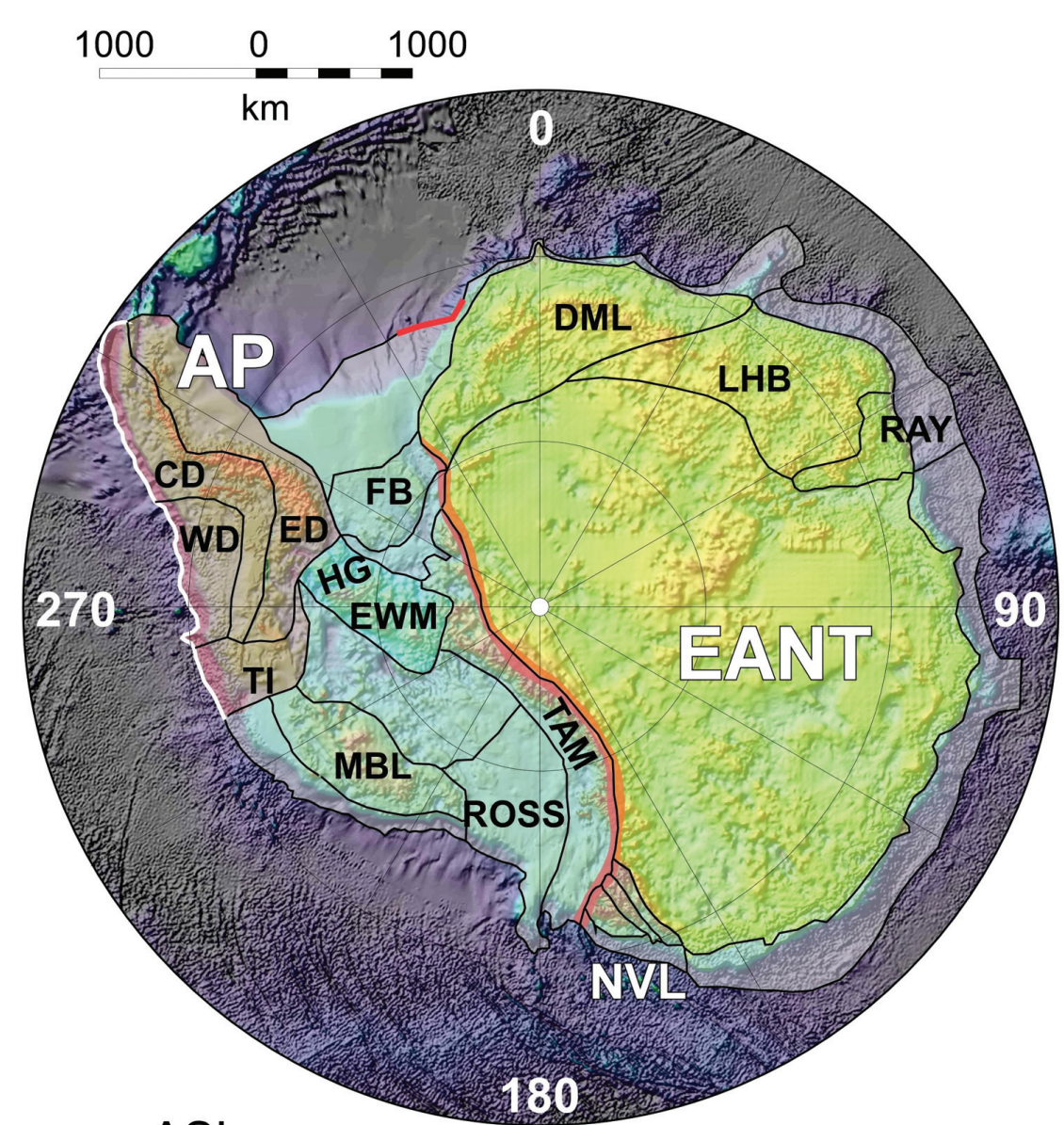

m ASL

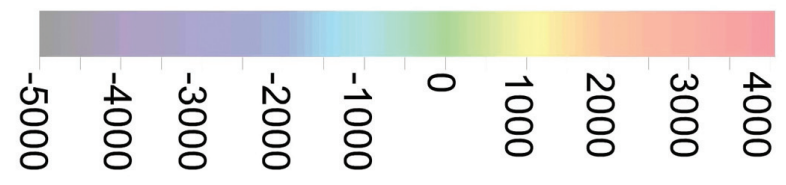

ment provinces (Fitzsimons, 2003) link EANT and cratonic Western Australia (WAUS, Australia west of the Tasman line), and consequently all reconstructions of Rodinia associate EANT (including the mostly unknown EANT shield) with WAUS in Neoproterozoic time. By further linking EANT to Gondwana at $\sim 550 \mathrm{Ma}$, Pangea at $\sim 320 \mathrm{Ma}$, and breakup at $\sim 175 \mathrm{Ma}$ with relative plate circuits we are able to construct a Synthetic Apparent Polar Wander (SAPW) path for EANT (Figure 3) based on Australian paleomagnetic data, Gondwana poles (550-320 Ma) (Torsvik and Van der Voo, 2002), and a global data compilation for the last 320 million years describing Pangea assembly and breakup (Torsvik et al., forthcoming). The SAPW path also includes palaeomagnetic data from EANT (listed in Torsvik and Van der Voo, 2002) whenever considered reliable. Within error, EANT poles match the SAPW path (Figure 3a).

The SAPW path (Table 2) predicts that a given location in EANT (Figure 3b) was located at tropical to subtropical southerly latitudes from about $1 \mathrm{Ga}$ to the Late Ordovician. However, Precambrian data are sparse: This portion of the SAPW path is based only on the $\sim 1070$ Ma Bangemall pole (Wingate et al., 2002), the 755 Ma Mundine pole (Wingate and Giddings, 2000) and several $\sim 600$ Ma poles from WAUS. During Late Ordovician and Silurian times ( 450-400 Ma), EANT drifted southward $(8-11 \mathrm{~cm} / \mathrm{yr}$; latitudinal velocity calculated from Figure 3b), followed by another phase of southward drift during the Carboniferous (350-300 Ma; 6-11 $\mathrm{cm} / \mathrm{yr}$ ). The Permo-Triassic (300-200 Ma) was characterized by northerly motion $(\sim 5 \mathrm{~cm} / \mathrm{yr})$; southerly drift $(2-7 \mathrm{~cm} / \mathrm{yr})$ again recommenced after $200 \mathrm{Ma}$. For the last $75 \mathrm{Ma}$, EANT has remained extremely stable $(\sim 0.6 \mathrm{~cm} / \mathrm{yr})$ near the South Pole.

EANT was located near the equator in the Early Paleozoic (Figure 3b). Marine invertebrates flourished in tropical seas and the continent hosted a varied range of climates, from deserts to tropical swamps. Excepting a period of 




FIGURE 2 Age of the ocean floor surrounding Antarctica. White arrows show "absolute" motion of some tectonic plates based on a moving hotspot frame for the last 5 million years. Red circles denote hotspot locations $(\mathrm{BH}=$ Bouvet; $\mathrm{KH}=$ Kerguelen; $\mathrm{MH}=$ Marion; $\mathrm{RH}=$ Reunion; $\mathrm{SH}=$ St. Helena; $\mathrm{TH}=$ Tristan). Large igneous provinces and other volcanic provinces (including seaward-dipping reflectors) are shown in brown and white. Active plate boundaries shown in black (midocean ridges) and extinct midocean ridges in grey. Inset figure shows isochrons based on present-day magnetic and gravity data. ScSea $=$ Scotia Sea (see Table 1 for more abbreviations). northerly drift into temperate latitudes near the TriassicJurassic boundary ( 200 Ma), EANT has remained in polar latitudes for the last 325 myr. Consequently, EANT has commonly been inundated by ice. However, the first recognized Phanerozoic glacial event-the short-lived Late Ordovician Hirnantian (ca. $443 \mathrm{Ma}$ ) glacial episode-occurred while EANT occupied temperate latitudes. During this time, NW Africa was located over the South Pole (Cocks and Torsvik, 2002). Conversely, during the Late Paleozoic glacial interval, commencing in the Late Carboniferous and lasting for almost 50 myr, the South Pole was located in EANT (Torsvik and Cocks, 2004). These Permo-Carboniferous glaciations resulted in deposition of widespread tills across South Pangea (Gondwana).

\section{WEST ANTARCTICA AND PALAEOMAGNETIC DATA}

In contrast with the great lumbering elephant of continental EANT, WANT comprises several distinct crustal blocks (Dalziel and Elliot, 1982), with independent Mesozoic and Cenozoic geotectonic histories (Figure 1). Because many are inadequately sampled paleomagnetically, it is difficult to portray their latitudinal story with great confidence.
Thus, we restrict our description and paleomagnetic analysis (following the pioneering work of Grunow, Dalziel, and coworkers) to the Antarctic Peninsula (AP), Thurston Island (TI), and the Ellesworth-Whitmore Mountains (EWM). In addition, relative movements between individual blocks or vs. EANT (e.g., Jurassic poles in Figure 4a) are sometimes only slightly greater than the resolving power of the paleomagnetic method.

AP has traditionally been treated as a single Mesozoic-toCenozoic continental arc system formed above an eastwarddipping paleo-Pacific subduction zone. Recent studies, however, suggest that AP consists of three fault-bounded terranes (WD, CD, and ED in Figure 1) that amalgamated in Late Cretaceous (Albian) time (Vaughan and Storey, 2000; Vaughan et al., 2002). However, for reasons of simplicity we keep AP blocks together in our reconstructions. Jurassic to Early Cretaceous (between $175 \mathrm{Ma}$ and $140 \mathrm{Ma}$ ) paleomagnetic poles from AP differ from the EANT SAPW path while Early Cretaceous (110 Ma) and younger poles overlap within error (Figure 4a). The data are therefore compatible with models that imply that AP moved away from EANT between 175 and 140 Ma while undergoing slow clockwise rotation (Weddell Sea opening at $\sim 5 \mathrm{~cm} / \mathrm{yr}$ ) (Figure $4 \mathrm{~b}$ ) fol- 
TABLE 1 Commonly Used Abbreviations

\begin{tabular}{|c|c|}
\hline AFR & Africa plate \\
\hline ANT & Antarctic plate \\
\hline AP & Antarctic Peninsula (now part of WANT) \\
\hline AUS & Australia \\
\hline DML & $\begin{array}{l}\text { Dronning Maud Land, includes the Grunehøgna terrane (part of the Kapvaal Archean core of the Kalahari craton, and the Maud orogen and } \\
\text { perhaps part of the Coats Land crustal block) (now part of EANT) }\end{array}$ \\
\hline EANT & East Antarctica \\
\hline EWM & Ellesworth-Whitmore Mountains (now part of WANT) \\
\hline FB & $\begin{array}{l}\text { Filchner Block (as defined by Studinger and Miller (1999), partly Coats Land cratonic block and partly extended and intruded "Afar } \\
\text { depression like" continental crust (Dalziel and Lawver, 2001) (now part of WANT) }\end{array}$ \\
\hline FI & Falkland Island (now part of SAM) \\
\hline HG & Haag (included in EWM) \\
\hline LHB & Lützow-Holm Bay (now part of EANT) \\
\hline KAL & Kalahari (now part of SAFR) \\
\hline MBL & Marie Byrd Land (now part of WANT) \\
\hline MEB & Maurice Ewing Bank (now part of SAM) \\
\hline NAZ & Nazca plate \\
\hline $\mathrm{P}$ & Patagonia (now part of SAM) \\
\hline PAC & Pacific plate \\
\hline RAY & Raynor Province (now part of EANT) \\
\hline SAFR & South Africa \\
\hline SAM & South American plate \\
\hline ScSea & Scotia Sea \\
\hline TI & Thurston Island (now part of WANT) \\
\hline WANT & West Antarctica \\
\hline WAUS & Western Australia, Cratonic Australia west of the Tasman line (now part of AUS) \\
\hline
\end{tabular}

lowed by convergence (Weddell Sea partial subduction) and clockwise rotation $(\sim 130-110 \mathrm{Ma})$ relative EANT (see also Grunow, 1993).

TI has few exposures, but available data indicate that TI was similar morphologically and tectonically to AP (Leat et al., 1993). 110 and 90 Ma poles (Figure 4a) are grossly similar to those from AP and EANT. In our reconstructions (Table 3) (Grunow, 1993), TI follows the overall motion of the AP blocks (see velocity pattern in Figure 4b). However, TI was emplaced in its present position at the southern end of the AP by some $\sim 300 \mathrm{~km}$ dextral movement and several degrees of clockwise rotation between $130 \mathrm{Ma}$ and $110 \mathrm{Ma}$.

EWM is a displaced segment of the cratonic margin (Schopf, 1969) whose past position is constrained by Late Cambrian (e.g., Grunow et al., 1987; Randall and MacNiocaill, 2004) and Jurassic paleomagnetic data (Grunow et al., 1987) (Figure 4a). EWM was probably located in the Natal Embayment of the African plate in Cambrian times and underwent $90^{\circ}$ counterclockwise rotation during Pangea breakup. A 175 Ma pole (Figure 4a) from EWM overlaps with a contemporaneous pole from AP (Figure 4a). However, we keep EWM near EANT during Late Jurassic-Early Cretaceous times by interpolating its position with the $\sim 175 \mathrm{Ma}$ pole and its current position fixed to EANT (here modeled to $120 \mathrm{Ma}$ ). This implies $\sim 1.3 \mathrm{~cm} / \mathrm{yr}$ of sinistral movement vs. EANT (Figure 4b).

\section{A PALEOGEOGRAPHIC PARADE}

Below we present eight paleogeographic maps from Neoproterozoic to Early Tertiary times. Global reconstructions are based on relative fits and paleomagnetic APW paths (Torsvik and Van der Voo, 2002; Torsvik et al., forthcoming), upgraded with reconstruction parameters for Antarctica and surrounding plates (Table 3). Paleomagnetism yields only latitudes and plate rotations, but longitudinal uncertainty can be minimized if the continent that has moved least in longitude can be identified and is used for reference: Africa is the best candidate (Burke and Torsvik, 2004). In order to reconstruct the continents in the best possible "absolute" manner we here use a hybrid reference frame based on merging an African mantle frame (O'Neil et al., 2005; Torsvik et al., forthcoming) and a paleomagnetic reference frame ( $>100$ Ma) back to the time of Pangea assembly ( $320 \mathrm{Ma})$. The paleomagnetic frame (110-320 Ma), calculated in African coordinates, was adjusted $5^{\circ}$ in longitude to correct for the longitudinal motion of Africa during the past 100 Ma inferred in the mantle reference frame. Reconstructions $250 \mathrm{Ma}$ and younger are therefore shown in a absolute sense with paleolongitudes and/or velocity vectors with respect to the Earth's spin axis. While it could prove possible to quantify uncertainties in velocity vectors for the mantle frame (see O'Neil et al., 2005), velocity vector uncertainties in the paleomagnetic frame (110-320 Ma) cannot be quantified since we assume "zero longitude" movement for Africa. 


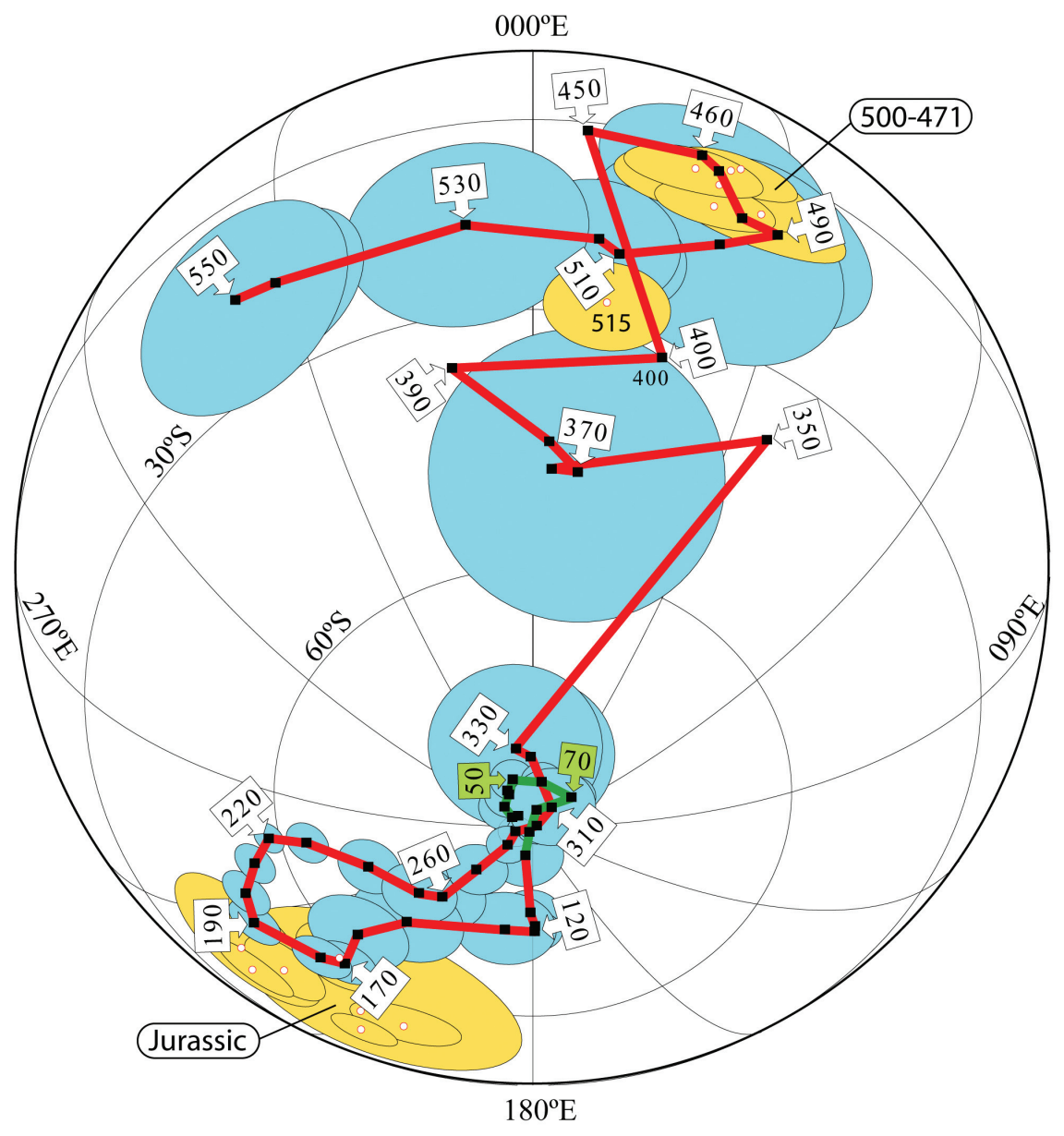

FIGURE 3a Synthetic APW path for EANT (Table 2, see text). Running mean poles (20 Ma window; 10 Ma intervals) are shown with A95 confidence circles (blue color). We also show actual input poles with $\mathrm{dp} / \mathrm{dm}$ ovals (light brown) from EANT that were included in the calculation of the SAPW path.



FIGURE 3b Latitude for a geographic location $\left(90^{\circ} \mathrm{S}\right)$ in EANT based on the SAPW path in Figure 3a. However, the last $100 \mathrm{Ma}$ is calculated from a moving hotspot frame. We show actual Phanerozoic latitudinal data from EANT (recalculated to $90^{\circ} \mathrm{S}$ ) with error bars. Yellow stars denote the times of reconstructions shown in the paper. PM = Palaeomagnetic data, and where the oldest section is based on paleomagnetic data from cratonic WAUS, then mean data from Gondwana (550-320 Ma), and finally global data until $110 \mathrm{Ma}$. 
TABLE 2 Phanerozoic Synthetic Apparent Polar Wander (SAPW) Path for EANT

\begin{tabular}{|c|c|c|c|c|}
\hline Age (Ma) & $\mathrm{N}$ & A95 & Lat. & Long. \\
\hline 0 & 18 & 3.0 & -87.8 & 308.3 \\
\hline 10 & 30 & 2.5 & -87.5 & 296.8 \\
\hline 20 & 23 & 2.9 & -86.1 & 307.4 \\
\hline 30 & 18 & 2.7 & -84.9 & 327.9 \\
\hline 40 & 19 & 2.8 & -85.3 & 326.6 \\
\hline 50 & 27 & 2.5 & -83.8 & 338.3 \\
\hline 60 & 30 & 2.4 & -84.4 & 010.3 \\
\hline 70 & 20 & 2.6 & -84.4 & 050.7 \\
\hline 80 & 23 & 2.8 & -87.8 & 010.3 \\
\hline 90 & 27 & 2.6 & -89.2 & 206.4 \\
\hline 100 & 11 & 4.2 & -86.1 & 191.6 \\
\hline 110 & 16 & 3.4 & -78.2 & 181.4 \\
\hline 120 & 24 & 2.3 & -76.1 & 179.0 \\
\hline 130 & 18 & 3.1 & -75.3 & 179.1 \\
\hline 140 & 10 & 5.6 & -75.2 & 191.9 \\
\hline 150 & 16 & 6.4 & -69.6 & 224.3 \\
\hline 160 & 14 & 6.0 & -62.9 & 228.1 \\
\hline 170 & 23 & 3.8 & -57.5 & 222.5 \\
\hline 180 & 26 & 3.6 & -55.3 & 226.0 \\
\hline 190 & 31 & 3.5 & -50.1 & 237.0 \\
\hline 200 & 35 & 3.2 & -51.9 & 243.9 \\
\hline 210 & 32 & 2.7 & -55.4 & 251.0 \\
\hline 220 & 29 & 2.0 & -58.5 & 257.8 \\
\hline 230 & 28 & 2.6 & -63.5 & 257.4 \\
\hline 240 & 35 & 3.7 & -70.1 & 248.5 \\
\hline 250 & 38 & 4.3 & -73.8 & 231.9 \\
\hline 260 & 26 & 4.8 & -75.7 & 224.9 \\
\hline 270 & 28 & 3.4 & -81.4 & 226.3 \\
\hline 280 & 57 & 2.4 & -86.4 & 228.9 \\
\hline 290 & 70 & 1.9 & -88.0 & 251.5 \\
\hline 300 & 39 & 2.4 & -89.6 & 074.2 \\
\hline 310 & 20 & 4.8 & -86.8 & 041.7 \\
\hline 320 & 9 & 9.3 & -81.4 & 358.9 \\
\hline 330 & 4 & 9.7 & -80.2 & 348.2 \\
\hline 340,350 & 1 & - & -38.2 & 035.2 \\
\hline 360 & 5 & 12.5 & -48.9 & 003.1 \\
\hline 370 & 8 & 16.7 & -49.0 & 007.7 \\
\hline 380 & 5 & 35.1 & -45.8 & 002.7 \\
\hline 390 & 2 & 138.6 & -36.4 & 348.7 \\
\hline 400 & 1 & - & -33.9 & 017.6 \\
\hline 440,450 & 1 & - & -1.8 & 006.1 \\
\hline 460 & 2 & 99.0 & -2.3 & 019.1 \\
\hline 470 & 5 & 13.8 & -4.4 & 021.2 \\
\hline 480 & 7 & 7.7 & -11.3 & 024.4 \\
\hline 490 & 7 & 12.7 & -11.5 & 028.9 \\
\hline 500 & 7 & 15.7 & -16.6 & 022.2 \\
\hline 510 & 9 & 7.6 & -21.7 & 010.4 \\
\hline 520 & 9 & 9.3 & -20.0 & 007.8 \\
\hline 530 & 8 & 13.7 & -17.9 & 352.1 \\
\hline 540 & 10 & 10.7 & -17.7 & 328.6 \\
\hline 550 & 7 & 14.1 & -16.8 & 323.1 \\
\hline
\end{tabular}

NOTE: $\mathrm{N}=$ number of poles; $\mathrm{A} 95=95$ percent confidence circle; Lat., Long. $=$ mean pole latitude, longitude.

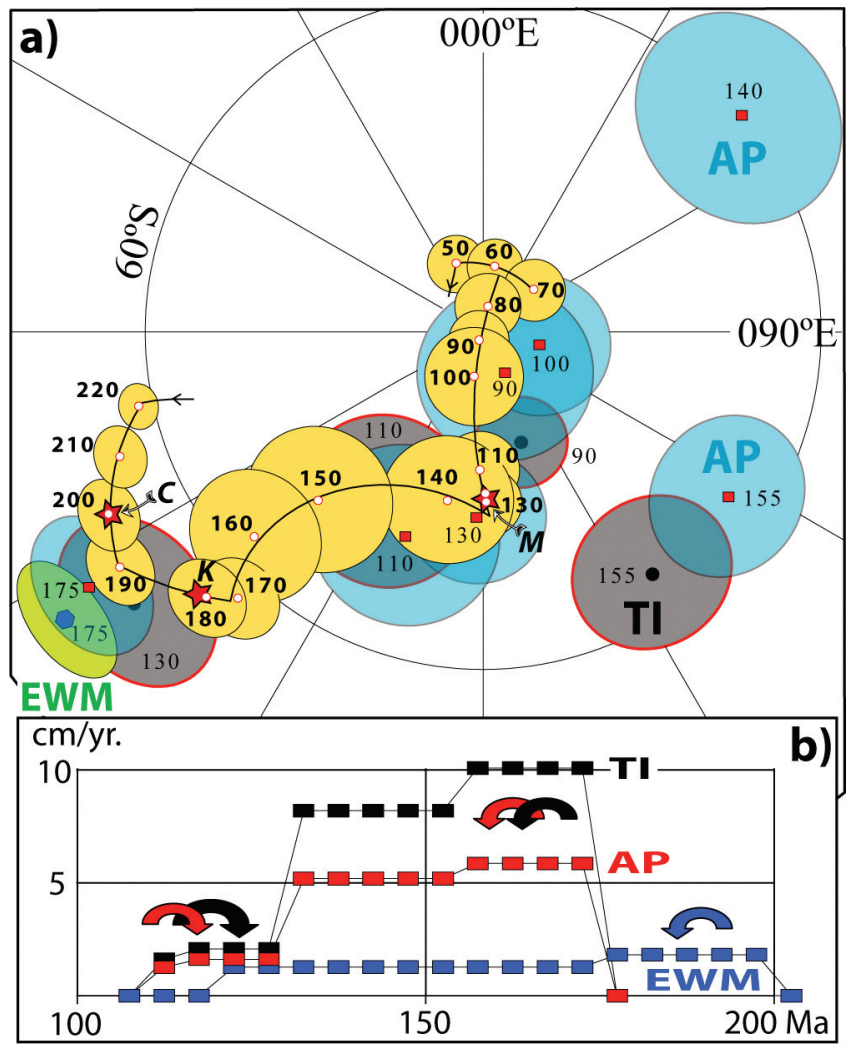

FIGURE 4 (a) Jurassic-Cretaceous poles from AP, EWM, and TI (mean poles with A95 ovals except 175 Ma EWM pole, dp/dm ovals) (Grunow, 1993). We also show the timing of some large igneous province events (red stars) that must have had an effect on Pangea in general $(\mathrm{C}=$ Central Atlantic Magmatic Province $)$ or directly affected Antarctica and its margin ( $\mathrm{K}=\mathrm{Karroo}$; $\mathrm{M}=$ Maud Rise/Madagascar Ridge). (b) Velocity for TI $\left(74^{\circ} \mathrm{S}, 248^{\circ} \mathrm{E}\right)$, AP $\left(72^{\circ} \mathrm{S}, 290^{\circ} \mathrm{E}\right)$ and EWM $\left(81^{\circ} \mathrm{S}, 271^{\circ} \mathrm{E}\right)$ relative to a fixed EANT. Colored arrows show sense of rotation relative to EANT. Poles in (a) are compared with the EANT SAPW path (yellow A95 ovals) as in Figure 3a for the last $200 \mathrm{Ma}$, but fitted with small circles that have RMS values less than $0.6^{\circ}$. Abrupt changes in the balance of forces driving and resisting plate motions should be noticed in the APW paths as cusps.

\section{Rodinia}

The identification of 1300-1000 Ma mountain belts (Grenvillian, Sveconorwegian, and Kibaran) presently located on different continents caused geologists of the 1970s to postulate a Precambrian supercontinent (e.g., Dewey and Burke, 1973). Thus, since the early 1990s, Precambrian reconstructions have consistently incorporated a vaguely resolved Neoproterozoic supercontinent, Rodinia (Hoffman, 1991; Dalziel, 1992, 1997; Torsvik et al., 1996) (Figure 5), postulated to have amalgamated about $1.0 \mathrm{Ga}$ and to have disintegrated at around 850-800 Ma (Torsvik, 
TABLE 3 Important Relative Reconstruction Parameters Discussed in the Text and Shown in Figures 5-9

\begin{tabular}{llrrr}
\hline Age & Continents & Lat. & \multicolumn{1}{c}{ Long. } & \multicolumn{1}{c}{ Ang. } \\
\hline $750-250$ & DML-KAL & 10.5 & 148.8 & -58.2 \\
$750-130$ & EANT-WAUS & 11.1 & -137.2 & -29.7 \\
$750-250$ & EWM-KAL & 56.8 & -086.1 & 92.7 \\
$750-250$ & FI-KAL & 31.6 & 164.8 & -119.5 \\
$750-250$ & MEB-KAL & 44.3 & -032.6 & 58.9 \\
750 & MBL-EANT & 68.4 & 023.9 & 57.1 \\
250,180 & AP-EANT & 72.3 & 086.8 & -35.5 \\
$250-99$ & MBL-EANT & 47.2 & 146.2 & -3.0 \\
250 & EWM/FB-EANT & 81.9 & 134.1 & 97.6 \\
250 & P-SAFR & 47.5 & -033.2 & 63 \\
250,180 & TI-EANT & 73.6 & 089.6 & -49.2 \\
180 & EWM/FB-EANT & 33.1 & 078.7 & -9.0 \\
180 & FI-SAFR & 32.2 & 164.0 & -119.3 \\
180 & MEB-SAFR & 44.9 & -032.9 & 58.7 \\
180 & P-SAFR & 47.5 & -033.1 & 61.3 \\
160 & AP-EANT & 23.9 & -027.0 & -11.9 \\
160 & EWM/FB-EANT & 69.9 & 093.7 & -23.5 \\
160 & P/FI/MEB-SAFR & 47.5 & -033.3 & 58.0 \\
160 & TI-EANT & 60.3 & -004.6 & -20.6 \\
130 & AP-EANT & 77.9 & 079.7 & -16.4 \\
130 & EWM/FB-EANT & 69.9 & 093.7 & -5.9 \\
130 & P/FI/MEB-SAFR & 48.5 & -033.4 & 56.1 \\
130 & TI-EANT & 74.6 & 102.1 & -31.1 \\
99 & EANT-AUS & 5.7 & 034.6 & 27.8 \\
99 & P/FI (SAM)-SAFR & 56.0 & -034.8 & 42.7 \\
50 & EANT-AUS & 13.0 & 032.9 & 24.7 \\
50 & MBL-EANT & 18.2 & 162.1 & -1.7 \\
50 & SAM-SAFR & 58.2 & -031.2 & 20.5 \\
\hline
\end{tabular}

NOTE: Lat., Long., Ang. = Euler pole latitude, longitude, angle. EWM, FB, TI, and AP fixed to EANT from ca. $110 \mathrm{Ma}$. Fits derived from this study, Dalziel (1997) (MBL), or interpolated from Grunow (1993) and Torsvik et al. (forthcoming).
2003). However, despite exhaustive research for more than 15 years, including new paleomagnetic studies as well as dating of mobile belts and rift sequences associated with Rodinia's breakup, the details of Rodinia remain obscure. The paleolatitudes of only a few of Rodinia's constituent continents are known at any given time, and in addition to nonconstrained longitudes, the hemispheric position of the individual continents is uncertain.

In Rodinia times WAUS and EANT were clearly linked as illustrated by the two-stage Albany-Fraser-Wilkes orogen (1350-1260 Ma and 1210-1140 Ma) (red shading in Figure 5) and also the older Mawson Craton (Fitzsimons, 2003). We do not associate India with WAUS-EANT as portrayed in many classic Rodinia reconstructions; rather, we consider them to have amalgamated during Gondwana assembly (Fitzsimons, 2000; Torsvik et al., 2001; Torsvik, 2003; Meert, 2003; Collins and Pisarevsky, 2005). The Napier Complex, LHR, and RAY (currently part of EANT) probably belonged to India prior to Pan-African collision (Figure 6).

Rodinia probably formed between $1100 \mathrm{Ma}$ and 1000 $\mathrm{Ma}$, and breakup probably occurred before 750 Ma. Rupture may have commenced with the opening of an equatorial ocean between western Laurentia and WAUS-EANT. Dronning Maud Land (DML; including the Grunehøgna terrane), and EWM (currently part of EANT and WANT) were probably linked to Kalahari (South Africa) during the Neoproterozoic (Figure 5).

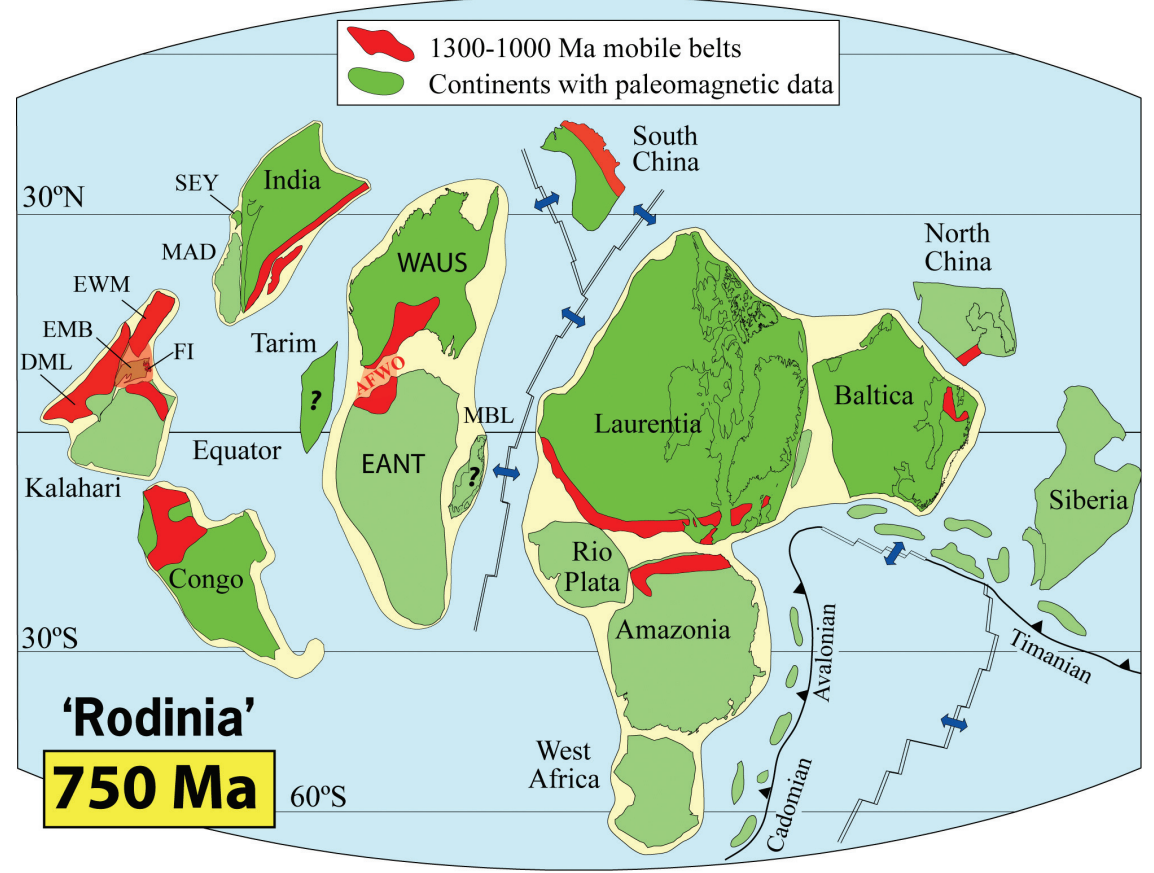

FIGURE 5750 million year reconstruction of Rodinia just after breakup ("Rodinia New" of Torsvik, 2003). Kalahari (no paleomagnetic data) has been modified to include DML, FI, MEB, and EWM. Outline of the Albany-Fraser-Wilkes Orogen (AFWO) in WAUS and EANT follows Fitzsimmon (2003). Low-latitude position of Tarim next to EANT and WAUS (Huang et al., 2005) is problematic since it has to be removed before collision with India. MBL after Dalziel (1997). However, the location and even existence of MBL at this time is uncertain-oldest MBL rocks are Cambrian but a Proterozoic basement age cannot be excluded (Leat et al., 2005). 
FIGURE 6 Late Cambrian reconstruction of Gondwana (inset globe) and a detailed reconstruction of EANT, SAFR (Kalahari), WAUS, India, and parts of present day SAM (P, FI, MEB). Craton outlines and orogenies mostly after Leat et al. (2005). Position of EWM (Table 3) is based on fitting Late Cambrian paleomagnetic data within error to also allow space for a smaller FB than of today. Terranes and blocks in the Natal Embayment were not affected by Pan-African deformation (see Table 1 for more abbreviations).

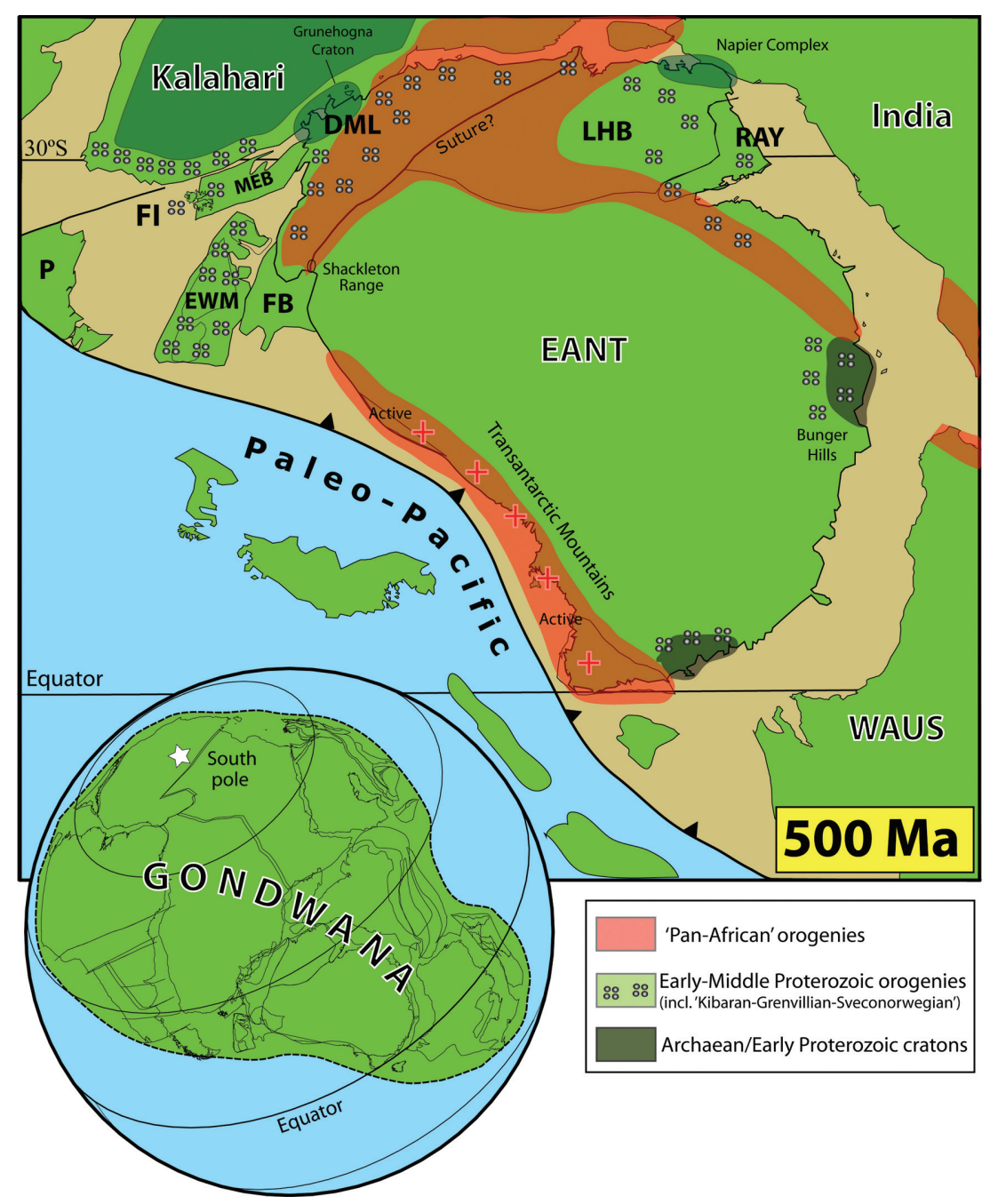

\section{Gondwana}

Breakup of Rodinia and the subsequent formation of Gondwana at $\sim 550 \mathrm{Ma}$ were marked by protracted Pan-African tectonism, one of the most spectacular mountain-belt building episodes in Earth history. Gondwana incorporated all of Africa, Madagascar, Seychelles, Arabia, India and EANT, most of South America and AUS, and probably some WANT blocks (EWM, FB?). The surface area of Gondwana totaled $95 \times 10^{6} \mathrm{~km}^{2}$, some 64 percent of today's landmasses or 19 percent of the Earth's surface (Torsvik and Cocks, forthcoming).

In the Late Cambrian, Gondwana (Figure 6, inset globe) stretched from polar (NW Africa) to subtropical northerly latitudes (AUS). EANT covered equatorial to subtropical southerly latitudes. As most reconstructions, we show the Falklands Islands (FI), the Maurice Ewing Bank (MEB), the EWM and FB block located near South Africa, and DML (Figure 6) (Table 3)-the Natal Embayment. The FI block was situated within a ca. $1.1 \mathrm{Ga}$ orogen that also included the Namaqua-Natal belt (SAFR) and the Maudheim province (DML). We further infer that the EWM terrane belonged to this province (Leat et al., 2005), and we associate all of the above terranes and blocks with Kalahari in Rodinia times (Figure 5). EWM basement is not exposed but $\sim 1.2 \mathrm{Ga}$ Grenvillian Haag Nunataks gneisses (Millar and Pankhurst, 1987) are considered to underlie it (Figures 5 and 6). Paleomagnetic (e.g., Randall and MacNiocaill, 2004), structural and stratigraphic data have been used to argue that EWM was situated near Coats Land (DML) until the Jurassic. In our slightly modified EWM fit (Figure 6) (Table 3) we maintain a similar connection until the early Jurassic ( 200 Ma). We allow space for a slightly smaller FB than of today by assuming later Mesozoic extension.

The Pan-African orogenies that stabilized EANT took place in two main zones (Figure 6): (1) in a broad region between the Shackleton Range, the Bunger Hills caused by collision with South Africa (including the Kalahari and Grunehøgna cratons, now part of EANT), and India (including the Napier Complex), and (2) along the Transantarctic 


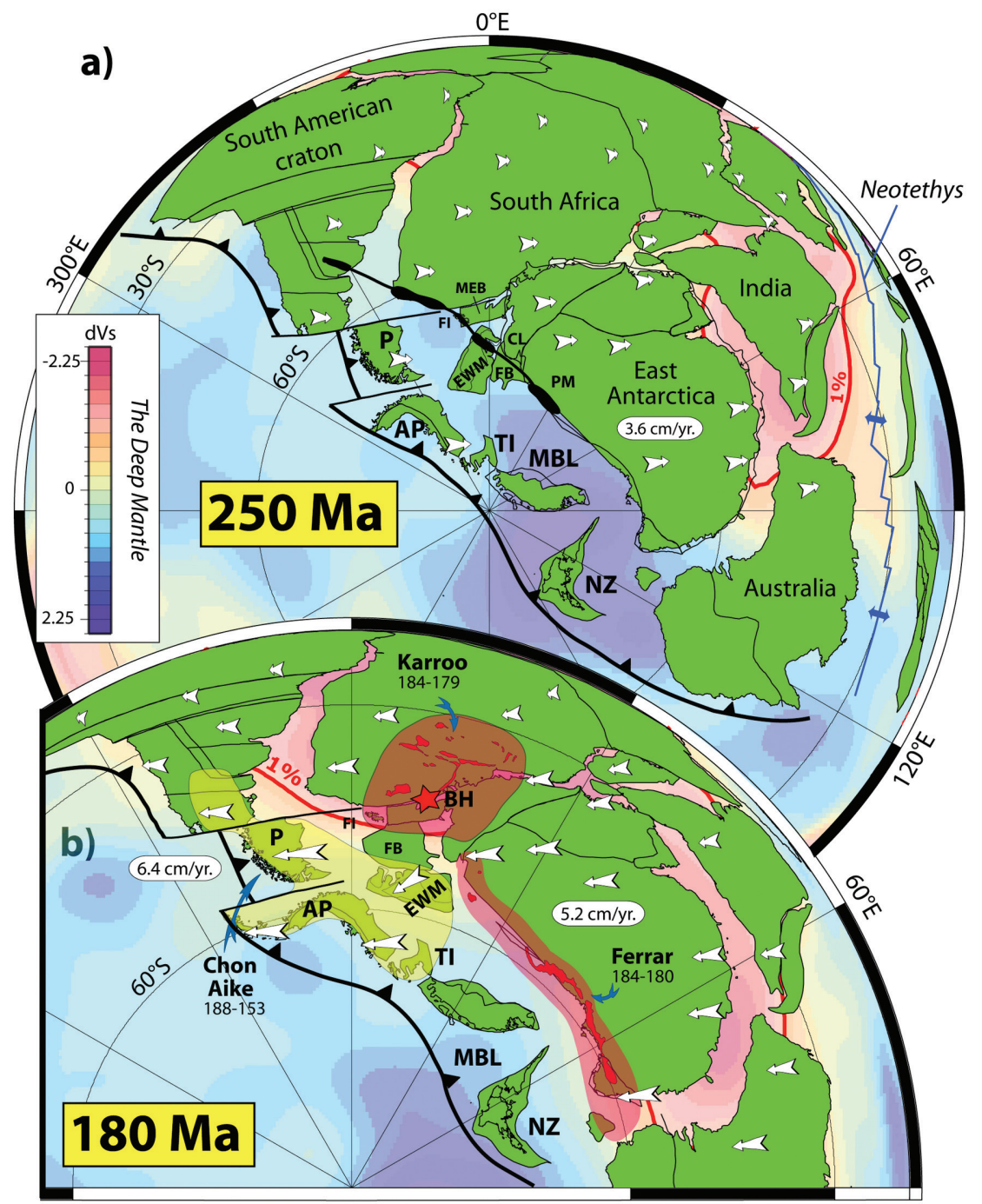

FIGURE 7 (a) $250 \mathrm{Ma}$ reconstruction. Black thick line denote the Permian-Early Mesozoic Gondwanide orogen (Dalziel and Grunow, 1992). $\mathrm{PM}=$ Pensacola Mountains (EANT); CL = Coats Land (DML). (b) 180 Ma reconstruction with distribution of the ca. 179-184 Ma Karroo and Ferrar volcanic provinces (LIPs) in SAFR, FI, and EANT and the silicic Chon Aike province (188-153 Ma) located to SAM (P), AP, EWM, and TI (Pankhurst et al., 2000). BH = Bouvet hotspot. White arrows denote absolute plate motion vectors. Mean plate velocities indicated for EANT and Patagonia (P) in (b). The background grid images represent structures in the lower mantle that are longlived and at regular intervals give rise to plumes and plume-related LIPs (Torsvik et al., 2006). The thick background red line in these images is the potential plume generation zone (e.g., underlying Bouvet in [b]) (see Table 1 for more abbreviations).
Mountains (Ross Orogeny), still active in Late Cambrian times (Leat et al., 2005, and references therein). The hub of Pan-African metamorphism between East Africa and EANT ( $580-550 \mathrm{Ma})$ (Jacobs and Thomas, 2004) is exposed in DML. Conversely, blocks in the adjoining Natal Embayment (e.g., EWM) (Figure 6) escaped both the East Africa-EANT and Ross orogens. Curtis (2001) suggested rifting along the Paleo-Pacific margin, otherwise characterized by active subduction, while Jacobs and Thomas (2004) argued for a lateral-escape scenario.

\section{Pangea}

From 320 Ma onward Gondwana, Laurussia, and intervening terranes merged to form the supercontinent Pangea. Pangea's main amalgamation occurred during the Carboniferous, but Pangea's dimensions were not static. Some continents were subsequently added along the supercontinent margins, and others rifted away (e.g., opening of Neotethys in Figure 7a) during the Late Paleozoic-Early Mesozoic (Torsvik and Cocks, 2004). Permo-Triassic structures in South America (Argentina), South Africa (Cape Fold Belt), FI, EWM, and ANT (Pensacola Mountains) suggest that an enigmatic Gondwanide orogen (Figure 7a) may have developed in response to subduction-related dextral compression along the convergent SW margin of Gondwana (Johnston, 2000).

Most plate tectonic models assume that the FI block originated off the SE coast of Africa and subsequently rotated $\sim 180^{\circ}$ from its current orientation in the Jurassic (e.g., Adie, 1952; Marshall, 1994; Dalziel and Lawver, 2001). This is required both by paleomagnetic data (e.g., Mitchell et al., 1986) from Jurassic dykes (Karroo aged) and by excellent correlations between the basement and the overlying Middle and Late Paleozoic strata of South Africa with the stratigraphy of the FI (Marshall, 1994). Restoration to a position adjacent to SE Africa is also suggested by the structural correlation of the eastern Cape Fold Belt with fold 
and thrust trends on the Falklands (Figure 7a). The collective data demand that FI have rotated nearly $180^{\circ}$. However, the timing (modeled here between $182 \mathrm{Ma}$ and $160 \mathrm{Ma}$ ) and the exact processes responsible for this during separation from southeast Africa remain unclear. The anticlockwise rotation of EWM relative to EANT would be even more difficult to explain if we took into account the presence of another continental crustal block, the Filchner Block (FB) (as defined by Studinger and Miller, 1999) thought to comprise cratonic blocks (Coats Land) and extended continental crust and not oceanic crust.

Pangea ruptured during the Jurassic, preceded by and associated with widespread magmatic activity, including the Karroo flood basalts and related dyke swarms in South Africa and the FI, and the Ferrar province in EANT (Figure $7 \mathrm{~b}$ ). The initial catastrophic outpouring of this deep plumerelated LIP event (Torsvik et al., 2006), possibly linked to the Bouvet hotspot, probably triggered the Toarchian (183 $\pm 1.5 \mathrm{Ma}$ ) global warming event (Svensen et al., 2007). Karroo and Ferrar magmatism partly coincided with the more prolonged Chon Aike rhyolite volcanism (Figure 7b), and subduction-related magmatism along the Proto-Pacific margin of Gondwana (Rapela et al., 2005).

Absolute plate motions (Figure 7) show a change from northeast (250 Ma) through southwest $(180 \mathrm{Ma})$ to southward motion from 170 Ma until the end of the Jurassic. A near $90^{\circ}$ cusp in the SAPW path (Figure 4a) at around $170 \mathrm{Ma}$ documents an abrupt change in plate driving forces. Unless caused by true polar wander we tentatively link this plate change to a combination of plume activity impinging the south Pangea lithosphere and subduction rollback. Because the subduction angle varied greatly, rollback must have been differential. Thus, we infer Patagonia (P) experienced a strong rollback effect, which we model (Figure 7a) with an offset of about $600 \mathrm{~km}$ compared to the present-day location in SAM. In our reconstructions SAM is broken into several discrete blocks whose borders behave as plate boundary scale deformation zones. This is necessary to understand and to reconstruct not only the FI drift story but also the Cretaceous opening history of the South Atlantic.

\section{CIRCUM-ANTARCTIC SEAFLOOR SPREADING SINCE THE LATE JURASSIC}

Preserved oceanic crust characterized by distinctive magnetic and gravity signatures allows us to reconstruct the age and extent of oceanic crust through time. However, subduction, complex seafloor spreading or massive volcanism can destroy or overprint this structure. In such cases geological and geophysical data from continental area are the only constraints for plate reconstructions. In the following we present circum-Antarctic reconstructions that take into account both continental and oceanic area evidences of plate motions. For oceanic areas we show the oceanic paleo-age modeled according to magnetic and gravity data of the preserved crust.

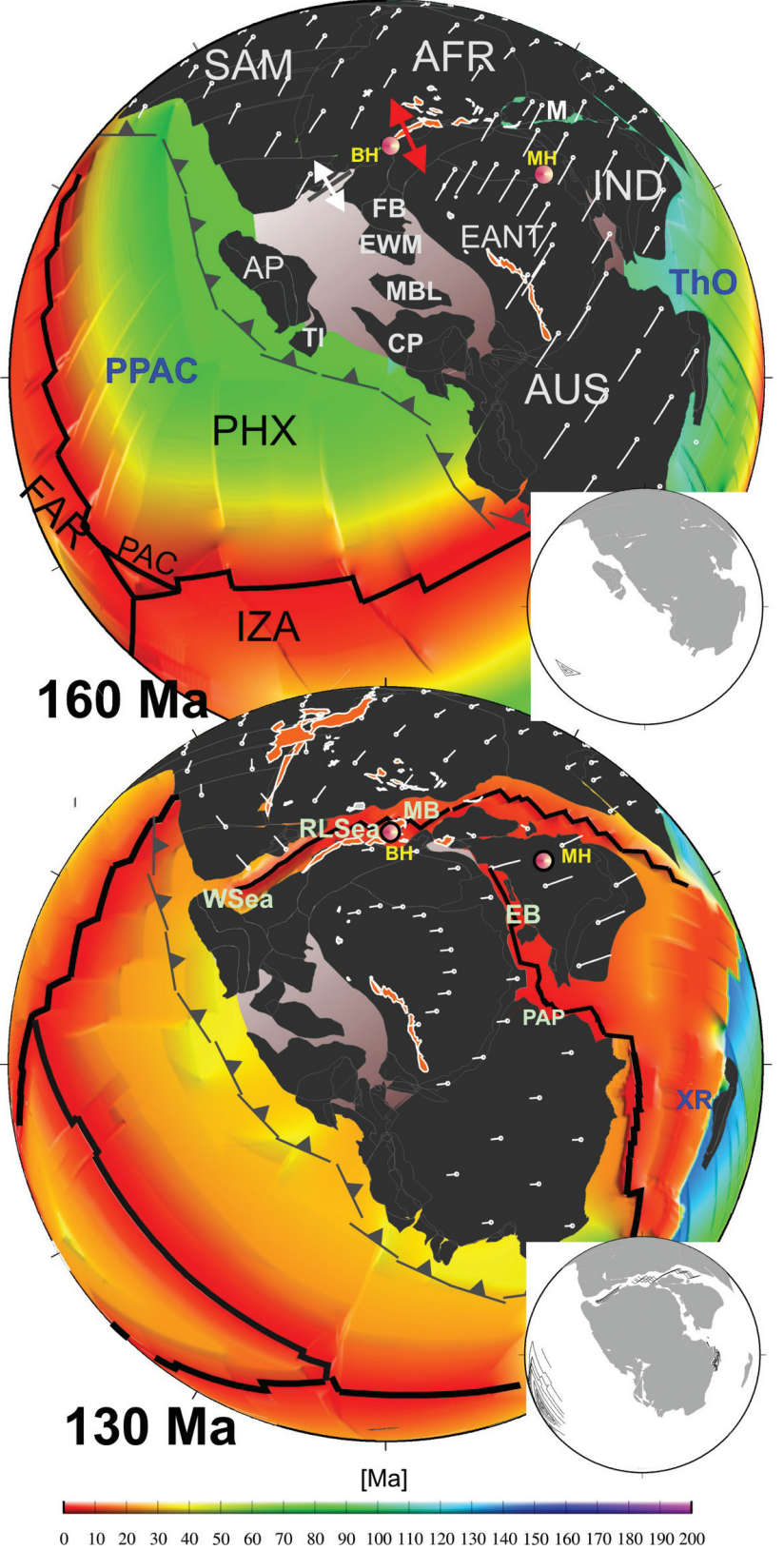

FIGURE 8 Oceanic paleo-age grids and reconstructed continental blocks of Gondwana at $160 \mathrm{Ma}$ and $130 \mathrm{Ma}$. Continental blocks: $\mathrm{CP}=$ Campbell Plateau; $\mathrm{M}=$ Madagascar (see Table 1 for more abbreviations). Oceanic plates: FAR $=$ Farallon; IZA = Izanaghi, PAC $=$ Pacific $;$ PHX = Phoenix. Oceanic basins: ThO-Neotethys, PPAC = Paleo-Pacific oceans, Wsea $=$ Weddell Sea, RLSea $=$ Riiser-Larsen Sea; $\mathrm{MB}=$ Mozambique basin $; \mathrm{EB}=$ Enderby Basin; PAP = Perth Abyssal Plain. Hotspots: $\mathrm{BH}=$ Bouvet, $\mathrm{MH}=$ Marion. XR indicates location of extinct ridges, toothed grey lines show location of subduction, thick white arrows between southern block of SAM and FB indicate extension. Red arrows indicate first Gondwana breakup in the RLSea. Absolute motion vectors shown as white lines. WANT blocks are connected by uncertain crust type (light brown color); this can be extended continental crust or oceanic crust that has subsequently been subducted or obducted. Inset figures show isochrons based on present-day magnetic and gravity data. 
In the case of a single preserved flank we assume symmetric spreading, and in the case of restoring complete oceanic basins, we assume symmetric spreading and rates according to the distances between the two margins whose locations are established by independent data (i.e., not oceanic crust data).

Our reconstructions show vectors of motions for the major continents, which are based on stage poles that indicate the average motion between the continent and underlying mantle for the last 5 million years before the age of the reconstruction. These stage poles are based on our hybrid reference frame and global plate circuit (Torsvik et al., forthcoming) that include finite rotation poles between tectonic plates inferred both quantitatively and qualitatively, based on paleomagnetic data, magnetic and gravity data, and geological data. Due to the complexity of the database, plate circuits, and range of errors involved in our analysis, a method to quantify the resulting errors of our motion vectors is not yet developed, but an estimation of several degrees are expected for a direction deviation.

Isotopic ages of rocks from the southernmost Andes and South Georgia Island, North Scotia Ridge revealed that the formation of oceanic crust in the Weddell Sea region occurred by the Late Jurassic $(150 \pm 1 \mathrm{Ma}$ ) (Mukasa and Dalziel, 1996), but interpretation of new geophysical data indicates that Gondwana breakup probably commenced in the Weddell Sea (Figure 8) at $\sim 160 \mathrm{Ma}$ and propagated clockwise around ANT (Ghidella et al., 2002; Jokat et al., 2003; König and Jokat, 2006). Early AFR-ANT spreading offshore DML has been dated to $153 \mathrm{Ma}$ (M24) in the Lazarev and Riiser-Larsen Seas (Roeser et al., 1996; Jokat et al., 2003). A new model for the early Indian-ANT spreading system in the Enderby Basin (Figure 8) places the onset of seafloor spreading at $130 \mathrm{Ma}$ (M9) (Gaina et al., 2003, 2007), consistent with the opening history between India and AUS in the Perth Abyssal Plain.

Early AUS-ANT spreading east of the Vincennes Fracture Zone $\left(\sim 105^{\circ} \mathrm{E}\right)$ has been identified by a Late Cretaceous ridge system between Chron $34(\sim 83.5 \mathrm{Ma})$ and $31(\sim 71 \mathrm{Ma})$ (Tikku and Cande, 1999). In the south Tasman Sea between eastern AUS and the Lord Howe Rise and New Zealand, seafloor spreading began in the late Cretaceous ( 83.5 Ma). Spreading propagated northward to the Coral Sea in the Tertiary, terminating at $52 \mathrm{Ma}$ (Gaina et al., 1998). Seafloor spreading east of AUS is combined with models that include incipient motion between EANT and WANT (Cande et al., 2000; Stock and Cande, 2002; Cande and Stock, 2004).

The evolution of the South Pacific region (Eagles et al., 2004) has been supplemented with reconstructed seafloor formed in the Pacific realm and subducted beneath WANT. The configuration of these "synthetic plates" was established on the basis of preserved magnetic lineations, paleogeography, regional geological data, and the rules of plate tectonics.

\section{Gondwana Breakup}

Long-lived subduction in the southern Pacific realm facilitated the amalgamation and accretion of several terranes to westernmost ANT (Vaughan and Storey, 2000). Recent geophysical data and models propose that extension between different continentally affiliated blocks of WANT achieved high degrees of extension but did not develop into seafloor spreading. Rotation, local subduction, and back-arc spreading may first have displaced and later reamalgamated AP blocks (Vaughan et al., 2002).

It has proved difficult to reach a consensus between motion described by paleomagnetic data and other geological and geophysical evidence. We therefore treat the Mesozoic WANT domain as a collection of island arc and continental blocks in a matrix of extended or not well-defined crust until $61 \mathrm{Ma}$ (i.e., when extension between EANT and WANT commenced) (Cande and Stock, 2004). Seafloor spreading in the Pacific region has been quantified using the oldest preserved magnetic anomalies that describe the relative motion between the nascent Pacific plate and neighboring Izanagi (completely subducted under Eurasia), Farallon (partially subducted under North America) and Phoenix (almost completely subducted under WANT, SAM, and AUS) plates. Most of the conjugate plates are now completely subducted and thus we assume symmetric seafloor spreading.

Late Jurassic and Early Cretaceous motion vectors show a general southward trend (Figure 8) that we attribute to subduction rollback. Africa and South America moved more slowly than the block formed by EANT, India, Seychelles, Madagascar, and AUS. Consequently, seafloor spreading started to develop between these two sub-blocks of Gondwana in the Weddell Sea, Riiser-Larsen Sea, Mozambique, and Somali basins. König and Jokat (2006) proposed that a long phase of extension and rifting took place in the southern Weddell Sea before the onset of seafloor spreading dated around $147 \mathrm{Ma}$ (M20). Older magnetic anomalies have been identified in the Riiser-Larsen Sea (M24 at $154 \mathrm{Ma}$ ) by Roeser et al. (1996), who consequently proposed $\sim 165 \mathrm{Ma}$ breakup time between EANT and Africa. At the same time, the southern Lazarev Sea (described as a continental margin) was affected by multiple rifting episodes accompanied by transient volcanism (Hinz et al., 2004).

Our 160 Ma reconstruction (Figure 8) shows the Bouvet plume located at the boundary between EANT and Africa. Although plume-related breakup is controversial, this reconstruction reinforces a possible relationship between breakup, seafloor spreading, and volcanism initiated at the Explora Wedge. This may also explain the multiple rift relocation in the southern Riiser-Larsen Sea and early seafloor spreading that later propagated west into the Weddell Sea. 
$130 \mathrm{Ma}$-Eastward Propagation of Seafloor Spreading: Antarctica-India-Australia Breakup

During the mid-Cretaceous, seafloor spreading propagated eastward from the Riiser-Larsen Sea to the Enderby basin between EANT and India (Gaina et al., 2007). At the same time, India broke off from Australia (Figure 8), forming ocean basins west of Australia (Perth, Cuvier, and Gascoyne abyssal plains) (Mihut and Müller, 1998; Heine et al., 2004).

It is unclear what triggered this event. The earliest magmatic activity in the Kerguelen area is dated to ca. $118 \mathrm{Ma}$ (Frey et al., 2000; Nicolaysen et al., 2001) and the EANT margin in the Enderby basin is a nonvolcanic margin. Magmatic activity, however, did occur further to the west (i.e., the 125 Ma Maud Rise LIP) (offshore DML and EANT) (Torsvik et al. 2006). We link this event with Bouvet hotspot activity (Figure 8, 130 Ma).

Motion vectors for the Indian-Madagascar-Seychelles triplet at $130 \mathrm{Ma}$ (Figure 8b) show rapid northward movement. We speculate that a possible Tethyan ocean ridge subduction under Eurasia caused the acceleration of India and also a southward ridge jump north of India and northwest of Australia (Heine et al., 2004). A significant cusp $\left(>90^{\circ}\right)$ is recognized in the SAPW path at around $130 \mathrm{Ma}$ signifying a major change in plate driving forces for EANT. Initial exhumation of the Transantarctic Mountains may have begun at this time in the Scott Glacier region (Fitzgerald and Stump, 1992), suggesting onset of extension between EANT and WANT.

\section{$99 \mathrm{Ma}$-Abrupt Change in Relative Velocity}

A dramatic acceleration of the Indian (and AFR) plate modified the seafloor spreading geometry north of Enderby Land and west of AUS (Müller et al., 2001). At the same time, the Pacific plate swerved and accelerated (Veevers, 2000) bringing long-lived subduction under the Australian and New Zealand plates to a halt (Figure 9). Transtensional regimes that followed this change in the Pacific plate motion led to the opening of the Tasman Sea east of AUS (Gaina et al., 1998) and rifting of the Chatham Rise, Campbell Plateau (and South New Zealand) from the MBL block (Cunningham et al., 2002). It is noteworthy that increased spreading rates between EANT and India (AFR), from $\sim 3 \mathrm{~cm} / \mathrm{yr}$ at $100 \mathrm{Ma}$ to $\sim 7 \mathrm{~cm} / \mathrm{yr}$ at $90 \mathrm{Ma}$ (Figure 10), was not associated with any abrupt changes in the SAPW path (Figure 4a).

\section{$50 \mathrm{Ma}$-Major Change in Plate Driving Forces as a Precursor to Opening of Oceanic Gateway}

While related to plume drift as opposed to a change in plate motion, the bend in the Hawaiian-Emperor (recently revised from $43 \mathrm{Ma}$ to $48 \mathrm{Ma}$ ) (Sharp and Clague, 2006) apparently does reflect a major tectonic event that affected much of the
Circum-Pacific realm. Besides the inception of rapid northward drift of the Australian plate that caused rapid accretion of oceanic crust on the EANT plate, a major plate tectonic reorganization has been recently reported between Australia and Antarctica (Whittaker et al., 2007). This major event

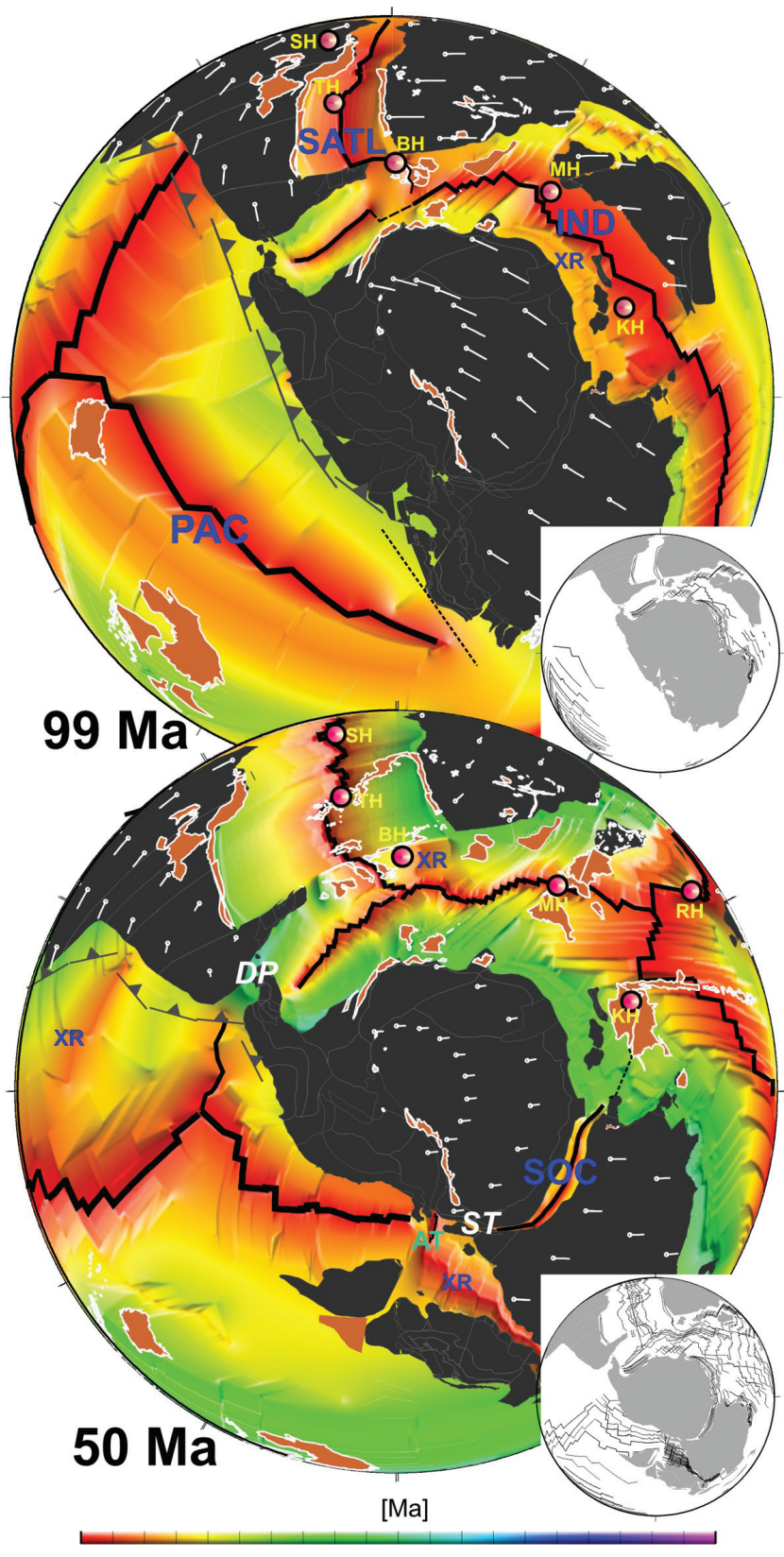

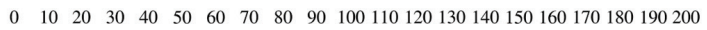

FIGURE 9 Paleo-age for reconstructed oceanic crust at $99 \mathrm{Ma}$ and $50 \mathrm{Ma}$. Oceanic basins. IND = Indian, SATL = South Atlantic; SOC $=$ Southern Ocean; AT = Adare Trough, $\mathrm{ST}=$ South Tasman; DP = Drake Passage. The Southern Hemisphere ocean gateways opened at around $33 \mathrm{Ma}$ and $30 \mathrm{Ma}$, respectively. Inset figures show isochrons based on present-day magnetic and gravity data (see Figure 8 and Table 1 for explanation of abbreviations). 


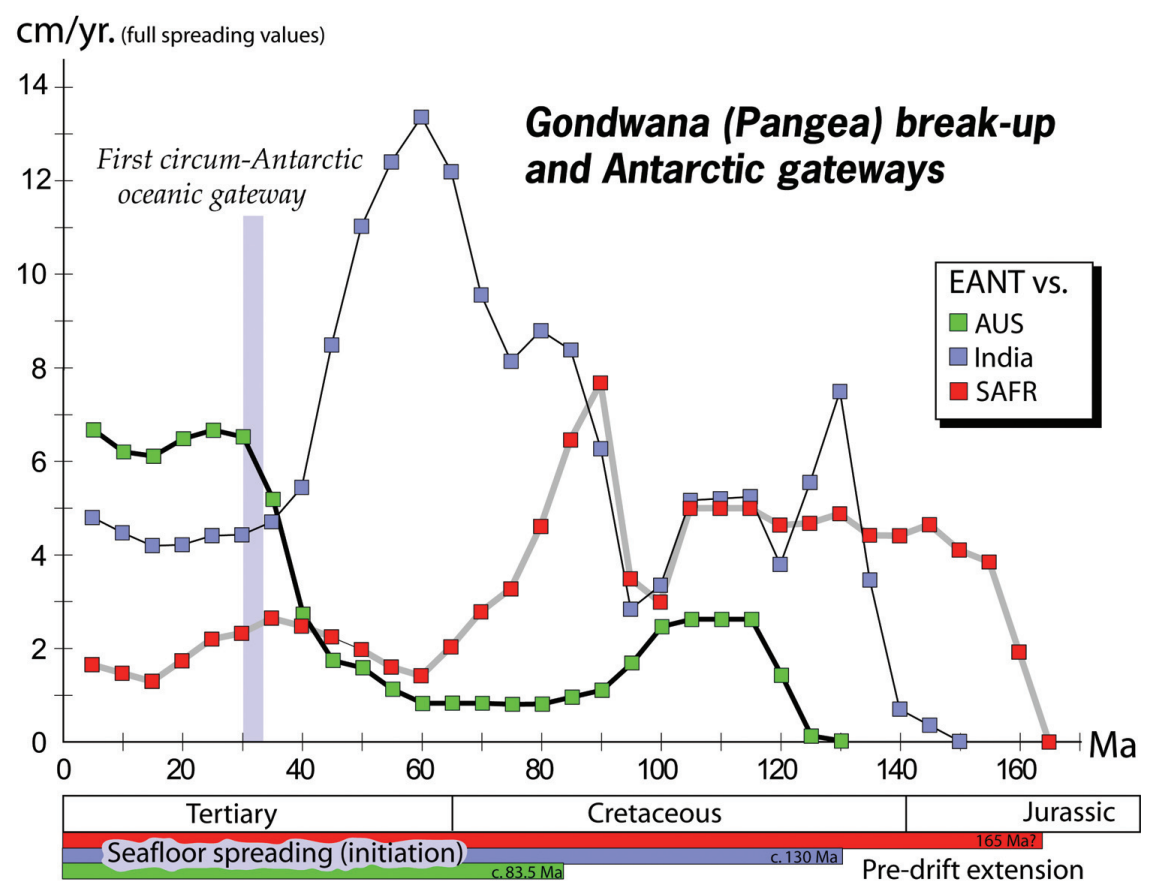

FIGURE 10 Mean plate rates of predrift deformation and seafloor spreading for AUS, India, and SAFR vs. EANT. (perhaps even global) that coincides with the HawaiianEmperor bend time was correlated to the subduction of the Pacific-Izanagi active spreading ridge and subsequent Mariana-Tonga-Kermadec subduction initiation (Whittaker et al., 2007).

Relative extension between EANT and WANT commenced in the Late Cretaceous-early Tertiary, but oceanic crust between these two plates was formed only between 45 Ma and $30 \mathrm{Ma}$ in the Adare Trough of the Ross Sea (Cande et al., 2000) (Figure 9). Rapid extension-related exhumation of the Transantarctic Mountains (TAM) at $\sim 55 \mathrm{Ma}$ is well documented (Fitzgerald and Gleadow, 1988; Fitzgerald, 2002), but the cause of this uplift is still unresolved. Two competing hypotheses seem pertinent: Fitzgerald et al. (1986) suggested a classic asymmetric extension process, while Stern and ten Brink (1989) proposed an elegant model based on the flexural up-warp of a broken, thin lithospheric plate. To date, neither model has been validated nor shown to be wrong. We suggest here that one "shoe" does not necessarily need to fit all: the Stern and ten Brink model (1989) appears to apply well to the Ross Sea sector of the range, outboard of the Wilkes subglacial basin, but may perhaps fit less well in the southern portion of the range. There the sub-ice surface inboard of the TAM achieves greater elevation, and the flexural profile fails. In this region an alternative mechanism-perhaps similar to the one proposed by Fitzgerald et al. (1986) — may become dominant.

In middle to late Eocene times relative motion between microcontinents south and west of Tasmania and the final detachment from ANT led to opening of the first circumAntarctic oceanic gateway (South Tasman), causing radical changes in oceanic circulation patterns (Brown et al., 2006).
By the dawn of the Oligocene ( 33.5 Ma) (Exon 2002) the gateway reached full marine conditions. Seafloor spreading in the Drake Passage and Scotia Sea region is generally considered to have commenced before $26 \mathrm{Ma}$ (Barker, 2001) or 29.7 Ma (Eagles and Livermore, 2002).

\section{EPILOGUE}

Far from static, Antarctica has traveled long distances, in both space and time. The most ancient fragments once basked beneath a tropical Precambrian sun, in communion with cratonic West Australia and enveloped in a loosely defined supercontinent, Rodinia. Playing an active role in Rodinia breakup and Gondwana assembly at the dawn of the Paleozoic, Antarctica commenced a long southward drift in Late Ordovician time. During the transit to its present polar position, Antarctica participated in the assembly of yet another supercontinent, Pangea. Jurassic and subsequent divorces left Antarctica surrounded by spreading ridges and marine circum-Antarctic gateways at the beginning of the Oligocene. Once the queen of the continental cotillion, Antarctica has danced away from the heart of it all to a splendid, ice-bound isolation at the bottom of the world-truly the Last Place on Earth.

\section{ACKNOWLEDGMENTS}

This paper was funded by the Geological Survey of Norway, the Norwegian Research Council, and StatoilHydro (PETROMAKS Frontier Science and Exploration no. 163395/S30). Reviewers Ian Dalziel, John Gamble, and Steve Cande are thanked for valuable comments. 


\section{REFERENCES}

Adie, R. J. 1952. The position of the Falkland Islands in a reconstruction of Gondwanaland Geological Magazine 89:401-410.

Barker, P. F. 2001. Scotia Sea regional tectonic evolution: Implications for mantle flow and palaeocirculation. Earth Science Reviews 55:1-39.

Brown, B., C. Gaina, and R. D. Muller. 2006. Circum-Antarctic palaeobathymetry: Illustrated examples from Cenozoic to recent times. Palaeogeography, Palaeoclimatology, Palaeoecology 231:158-168.

Burke, K., and T. H. Torsvik. 2004. Derivation of large igneous provinces of the past 200 million years from long-term heterogeneities in the deep mantle. Earth and Planetary Science Letters 227:531-538.

Cande, S. C., and J. M. Stock. 2004. Pacific-Antarctic-Australia motion and the formation of the Macquarie Plate. Geophysical Journal International 157:399-414.

Cande, S. C., J. Stock, R. D. Müller, and T. Ishihara. 2000. Cenozoic motion between East and West Antarctica. Nature 404:145-150.

Cocks, L. R. M., and T. H. Torsvik. 2002. Earth Geography from 500 to 400 million years ago: A faunal and palaeomagnetic review. Journal of the Geological Society of London 159:631-644.

Collins, A. S., and S. A. Pisarevsky. 2005. Amalmagating eastern Gondwana: The evolution of the Circum-Indian Orogens. Earth Science Reviews 71:229-270.

Cunningham, A.P., R. D. Larter, P. F. Barker, K. Gohl, and F. O. Nitsche. 2002. Tectonic evolution of the Pacific margin of Antarctica. 2. Structure of Late Cretaceous-early Tertiary plate boundaries in the Bellingshausen Sea from seismic reflection and gravity data. Journal of Geophysical Research 107, doi:10.1029/2002JB001897.

Curtis, M. L. 2001. Tectonic history of the Ellesworth Mountains, West Antarctica: Reconciling a Gondwana enigma. Geological Society of America Bulletin 113:939-958.

Dalziel, I. W. D. 1992. On the organization of American plates in the Neoproterozoic and the breakout of Lauretia. GSA Today 2:237-241.

Dalziel, I. W. D. 1997. Neoproterozoic-Paleozoic geography and tectonics: Review, hypothesis, environmental speculation. Geological Society of America Bulletin 109:16-42.

Dalziel, I. W. D., and D. H. Elliot. 1982. West Antarctica: Problem child of Gondwanaland. Tectonics 1:3-19.

Dalziel, I. W. D., and A. M. Grunow. 1992. Late Gondwanide tectonic rotations within Gondwanaland. Tectonics 11:603-606.

Dalziel, I. W. D., and L. S. Lawver. 2001. The lithospheric setting of the west Antarctic ice sheet. In The West Antarctic Ice Sheet; Behavior and Environment, eds. R. B. Alley and R. A. Bindschadler. Antarctic Research Series 77:29-44. Washington, D.C.: American Geophysical Union.

Dewey, J. F., and K. Burke. 1973. Tibetan, Variscan and Precambrian basement reactivation: Products of continental collision. Journal of Geology 81:683-692.

Eagles, G., and R. A. Livermore. 2002. Opening history of Powell Basin, Antarctic Peninsula. Marine Geology 185:195-205.

Eagles, G., K. Gohl, and R. D. Larter. 2004. High resolution animated reconstruction of the South Pacific and West Antarctic margin. Geochemistry, Geophysics, Geosystems 5:Q07002, doi:10.1029/2003GC000657.

Exon, N. 2002. Drilling reveals climatic consequence of Tasmanian Gateway opening. Eos Transactions of the American Geophysical Union 83:253-259.

Fitzgerald, P. 2002. Tectonics and landscape evolution of the Antarctic plate since the breakup of Gondwana, with an emphasis on the West Antarctic Rift System and the Trans Antarctic Mountains. In Antarctica at the Close of a Millennium. Royal Society of New Zealand Bulletin 35:453-469.

Fitzgerald, P. G., and A. J. W. Gleadow. 1988. Fission track geochronology, tectonics and structure of the Transantarctic Mountains in Northern Victoria Land, Antarctica. Isotope Geoscience 73:169-198.
Fitzgerald, P. G., and E. Stump 1992. Early Cretaceous uplift in the southern Sentinel Range, Ellsworth Mountains, West Antarctica. In Recent Progress in Antarctic Earth Science, eds. Y. Yoshida, K. Kaminuma, and K. Shiraishi, pp. 331-340, TERRAPUB, Tokyo.

Fitzgerald, P. G., M. Sandiford, P. J. Barrett, and A. J. W. Gleadow. 1986. Asymmetric extension associated with uplift and subsidence of the Transantarctic Mountains. Earth and Planetary Science Letters 81:67-78.

Fitzsimons, I. C. E. 2000. Grenville-age basement provinces in East Antarctica: Evidence for three separate collision orogens. Geology 28:879-882

Fitzsimons, I. C. E. 2003. Proterozoic basement provinces of southern and southwestern Australia, and their correlations with Antarctica. In Proterozoic East Gondwana: Supercontinent Assembly and Breakup, eds. M. Yoshida, B. F. Windley, and S. Dasgupta. Geological Society of London Special Publication 206:93-130.

Frey, F. A., M. F. Coffin, P. J. Wallace, D. Weis, X. Zhao, S. W. Wise, Jr., V. Waehnert, D. A. H. Teagle, P. J. Saccocia, D. N. Reusch, M. S. Pringle, K. E. Nicolaysen, C. R. Neal, R. D. Müller, C. L. Moore, J. J. Mahoney, L. Keszthelyi, H. Inokuchi, R. A. Duncan, H. Delius, J. E. Damuth, D. Damasceno, H. K. Coxall, M. K. Borre, F. Boehm, J. Barling, N. T. Arndt, and M. Antretter. 2000. Origin and evolution of a submarine large igneous province; the Kerguelen Plateau and Broken Ridge, southern Indian Ocean. Earth and Planetary Science Letters 176:73-89.

Gaina, C., D. R. Müller, J.-Y. Royer, J. M. Stock, J. L. Hardebeck, and P. Symonds. 1998. The tectonic history of the Tasman Sea; a puzzle with 13 pieces. Journal of Geophysical Research 6:12413-12433.

Gaina, C., R. D. Müller, B. Brown, and T. Ishihara. 2003. Microcontinent formation around Australia. In Evolution and Dynamics of the Australian Plate, eds. R. R. Hills and R. D. Müller. Geological Society of Australia Special Publication 22 and Geological Society of America Special Paper 372:405-416.

Gaina, C., R. D. Müller, B. Brown, T. Ishihara, and K. S. Ivanov. 2007. Breakup and early seafloor spreading between India and Antarctica. Geophysical Journal International, doi:10.1111/j.1365246X.2007.03450.x

Ghidella, M. E., G. Yáôez, and J. LaBreque. 2002. Raised tectonic implications for the magnetic anomalies of the western Weddell Sea. Tectonophysics 347:65-86.

Grunow, A. M. 1993. New paleomagnetic data from the Antarctic Peninsula and their tectonic implications. Journal of Geophysical Research 98:13815-13833.

Grunow, A. M., I. W. D. Dalziel, and D. V. Kent. 1987. Ellsworth-Whitmore Mountains crustal block, western Antarctica: New paleomagnetic results and their tectonic significance. In Gondwana Six: Structure, Tectonics and Geophysics, ed. G. D. McKenzie, American Geophysical Union Geophysical Monograph 40:161-172.

Harley, S. L. 2003. Archaean-Cambrian crustal development of East Antarctica: Metamorphic characteristics and tectonic implication. In Proterozoic East Gondwana: Supercontinent Assembly and Breakup, eds. M. Yoshida, B. F. Windley, and S. Dasgupta. Geological Society of London Special Publication 206:203-230.

Heine, C., R. D. Müller, and C. Gaina. 2004. Reconstructing the Lost Eastern Tethys Ocean Basin: Convergence history of the SE Asian margin and marine gateways. In Continent-Ocean Interactions in Southeast Asia, eds. P. Clift, D. Hayes, W. Kuhnt, and P. Wang. American Geophysical Union Geophysical Monograph 149:37-54.

Hinz, K., S. Neben, Y. B. Gouseva, and G. A. Kudryavtsev. 2004. A compilation of geophysical data from the Lazarev Sea and the Riiser-Larsen Sea, Antarctica. Marine Geophysical Researches 25:233-245.

Hoffman, P. F. 1991. Did the breakout of Laurentia turn Gondwana inside out? Science 252:1409-1411.

Huang, B., B. Xu, C. Zhang, Y. Li, and R. Zhu. 2005. Paleomagnetism of the Baiyisi volcanic rocks (ca. $740 \mathrm{Ma}$ ) of Tarim, Northwest China: A continental fragment of Neoproterozoic Western Australia. Precambrian Research 142:83-92. 
Jacobs, J., and R. J. Thomas. 2004. Himalayan-type indenter-escape tectonics model of the southern part of the late Neoproterozoic-early Paleozoic East African-Antarctic orogen. Geology 32:721-724.

Johnston, S. T. 2000. The Cape Fold Belt and Syntaxis and the rotated Falkland Islands: Dextral transpressional tectonics along the southwest margin of Gondwana. Journal of African Earth Sciences 31:51-63.

Jokat, W., T. Boebel, M. König, and U. Meyer. 2003. Timing and geometry of early Gondwana breakup. Journal of Geophysical Research 108, doi:10.1029/2002JB001802.

König, M., and W. Jokat. 2006. The Mesozoic breakup of the Weddell Sea. Journal of Geophysical Research 111, doi:10.1029/2005JB004035.

Leat, P. T., B. C. Storey, and R. J. Pankhurst. 1993. Geochemistry of Palaeozoic-Mesozoic Pacific rim orogenic magmatism, Thurston Island area, West Antarctica. Antarctic Science 5:281-296.

Leat, P. T., A. A. Dean, I. L. Millar, S. P. Kelley, A. P. M. Vaughan, and T. R. Riley. 2005. Lithosphere mantle domains beneath Antarctica. In Terrane Processes at the Margins of Gondwana, eds. A. P. M. Vaughan, P. T. Leat, and R. J. Pankhurst. Geological Society of London Special Publication 246:359-380.

Lythe, M. B., D. G. Vaughan, and the BEDMAP Consortium. 2000. BEDMAP — bed topography of the Antarctic. 1:10,000,000 scale map. BAS (Misc) 9. Cambridge: British Antarctic Survey.

Marshall, J. E. A. 1994. The Falkland Islands: A key element in Gondwana paleogeography. Tectonics 13:499-514.

Meert, J. G. 2003. A synopsis of events related to the assembly of eastern Gondwana. Tectonophysics 362:1-40.

Mihut, D., and R. D. Müller. 1998. Volcanic margin formation and Mesozoic rift propagators in the Cuvier abyssal plain off Western Australia. Journal of Geophysical Research 103:27135-27150.

Millar, I. L., and R. J. Pankhurst. 1987. Rb-Sr geochronology of the region between the Arctic Peninsula and the Transantarctic Mountains: Haag Nunataks and Mesozoic granitoids. In Gondwana Six: Structure, Tectonics and Geophysics, ed. G. D. McKenzie, pp. 151-160. American Geophysical Union Monograph 40.

Mitchell, C., G. K. Taylor, K. G. Cox, and J. Shaw. 1986. Are the Falklands a rotated microplate? Nature 319:131-134.

Mukasa, S. B., and I. W. D. Dalziel. 1996. Southernmost Andes and South Georgia Island, North Scotia Ridge: Zircon U-Pb and muscovite $40 \mathrm{Ar} / 39 \mathrm{Ar}$ age constraints on tectonic evolution of Southwestern Gondwanaland. Journal of South American Earth Sciences 9(5):349-365.

Müller, R. D., C. Gaina, and W. R. Roest. 2001. A recipe for microcontinent formation. Geology 29:203-206.

Nicolaysen, K., S. Bowring, F. Frey, D. Weis, S. Ingle, M. S. Pringle, and M. F. Coffin. 2001. Provenance of Proterozoic garnet-biotite gneiss recovered from Elan Bank, Kerguelen Plateau, southern Indian Ocean. Geology 29:235-238.

O'Neill, C., R. D. Müller, and B. Steinberger. 2005. On the uncertainties in hot spot reconstructions and the significance of moving hot spot reference frames. Geochemistry, Geophysics, Geosystems 6:Q04003, doi:10.1029/2004GC000784.

Pankhurst, R. J., T. R. Riley, C. M. Fanning, and S. P. Kelley. 2000. Episodic silicic volcanism in Patagonia and the Antarctic Peninsula: Chronology of magmatism associated with the break-up of Gondwana. Journal of Petrology 41:605-625.

Randall, D. E., and C. MacNiocaill. 2004. Cambrian palaeomagnetic data confirm a Natal embayment location for the Ellsworth-Whitmore Mountains, Antarctica, in Gondwana reconstructions. Geophysical Journal International 157:105-116.

Rapela, C. W., R. J. Pankhurst, C. M. Fanning, and F. Herve. 2005. Pacific subduction coeval with the Karoo mantle plume: The Early Jurassic Subcordilleran belt of northwestern Patagonia. In Terrane Processes at the Margins of Gondwana, eds. A. P. M. Leat and R. J. Pankhurst. Geological Society of London Special Publication 246:217-239.
Roeser, H. A., J. Fritsch, and K. Hinz. 1996. The development of the crust off Dronning Maud Land, East Antarctica. In Weddell Sea Tectonics and Gondwana Break-up, eds. B. C. Storey, E. C. King, and R. Livermore. Geological Society of London Special Publication 108:243-264.

Schopf, J. M. 1969. Ellsworth Mountains: Position in West Antarctica due to seafloor spreading. Science 164:63-66.

Sharp, W. D., and D. A. Clague. 2006. 50-Ma initiation of HawaiianEmperor bend records major change in Pacific plate motion. Science 313:1281-1284.

Stern, T. A., and U. S. ten Brink. 1989. Flexural uplift of the Transantarctic Mountains. Journal of Geophysical Research 94:10315-10330.

Stock, J. M., and S. C. Cande. 2002. Tectonic history of the Antarctic seafloor in the Australia-New Zealand-South Pacific sector: Implications for Antarctic continental tectonics. In Antarctica at the Close of a Millennium, eds. J.A. Gamble, D. N. B. Skinner, and S. Henrys. Royal Society of New Zealand Bulletin 35:252-259.

Studinger, M., and H. Miller. 1999. Crustal structure of the Filchner-Ronne shelf and Coats-Land, Antarctica, from gravity and magnetic data: Implications for the break-up of Gondwana. Journal of Geophysical Research 104:20379-20394.

Svensen, H., S. Planke, L. Chevallier, A. Malthe-Sørensen, F. Corfu, and B. Jamtveit. 2007. Hydrothermal venting of greenhouse gases triggering Early Jurassic global warming. Earth and Planetary Science Letters 256:554-566.

Tikku, A. A., and S. C. Cande. 1999. The oldest magnetic anomalies in the Australian-Antarctic Basin: Are they isochrons? Journal of Geophysical Research 104:661-677.

Torsvik, T. H. 2003. The Rodinia jigsaw puzzle. Science 300:1379-1381.

Torsvik, T. H., and L. R. M. Cocks. 2004. Earth geography from 400 to 250 million years: A palaeomagnetic, faunal and facies review. Journal of the Geological Society of London 161:555-572.

Torsvik, T. H., and L. R. M. Cocks. Forthcoming. The Lower Palaeozoic palaeogeographical evolution of the Northeastern and Eastern periGondwanan margin from Turkey to New Zealand. Geological Society of London Special Publication.

Torsvik, T. H., and R. Van der Voo. 2002. Refining Gondwana and Pangea palaeogeography: Estimates of Phanerozoic (octupole) non-dipole fields. Geophysical Journal International 151:771-794.

Torsvik, T. H., M. A. Smethurst, J. G. Meert, R. Van der Voo, W. S. McKerrow, M. D. Brasier, B. A. Sturt, and H. J. Walderhaug. 1996. Continental break-up and collision in the Neoproterozoic and Palaeozoic: A tale of Baltica and Laurentia. Earth Science Reviews 40:229-258.

Torsvik, T. H., L. M. Carter, L. D. Ashwal, S. K. Bhushan, M. K. Pandit, and B. Jamtveit. 2001. Rodinia refined or obscured: Palaeomagnetism of the Malani Igneous Suite (NW India). Precambrian Research 108:319-333.

Torsvik, T. H., M. A. Smethurst, K. Burke, and B. Steinberger. 2006. Large Igneous Provinces generated from the margins of the Large Low Velocity Provinces in the deep mantle. Geophysical Journal International 167:1447-1460.

Torsvik, T. H., R. D. Müller, R. Van der Voo, B. Steinberger, and C. Gaina. Forthcoming. Global plate motion frames: Toward a unified model. Reviews of Geophysics.

Vaughan, A. P. M., and B. C. Storey. 2000. The Eastern Palmer Land shear zone: A new terrane accretion model for the Mesozoic development of the Antarctic Peninsula magmatic arc. Journal of the Geological Society of London 157:1243-1256.

Vaughan, A. P. M., S. P. Kelley, and B. C. Storey. 2002. Mid-Cretaceous ductile deformation on the Eastern Palmer Land Shear Zone, Antarctica, and implications for timing of Mesozoic terrane collision. Geological Magazine 139:465-471.

Veevers, J. J. 2000. Change of tectono-stratigraphic regime in the Australian plate during the $99 \mathrm{Ma}$ (mid-Cretaceous) and $43 \mathrm{Ma}$ (mid-Eocene) swerves of the Pacific. Geology 28:47-50. 
Whittaker, J. M., R. D. Müller, G. Leitchenkov, H. Stagg, M. Sdrolias, C. Gaina, and A. Goncharov. 2007. Major Australia-Antarctic plate reorganization at Hawaiian-Emperor bend time. Science 318:83-87.

Wingate, M. T. D., and J. W. Giddings. 2000. Age and palaeomagnetism of the Mundine Well dyke swarm, Western Australia: Implications for an Australia-Laurentia connection at $755 \mathrm{Ma}$. Precambrian Research 100:335-357.
Wingate, M. T. D., S. A. Pisarevsky, and D. A. D. Evans. 2002. Rodinia connections between Australia and Laurentia: NoSWEAT, no AUSWUS? Terra Nova 14:121-128. 